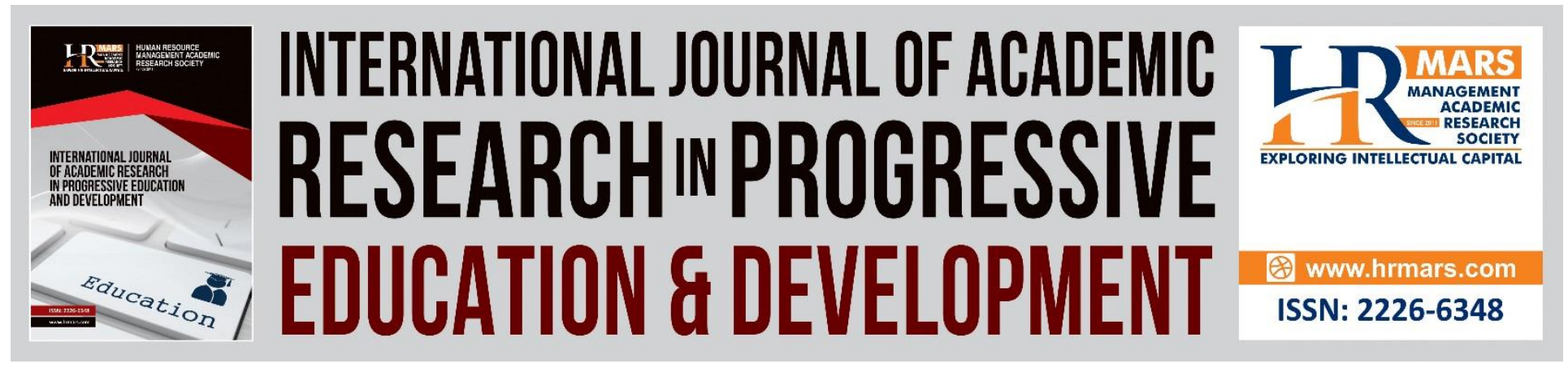

\title{
An Efficiency Analysis of Lecturer Engagement Through Virtual Learning Using Microsoft Teams During Covid-19 Pandemic
}

Sarahiza Mohmad, Mohd Syahril Ibrahim, Wan Normila Mohamad, Mat Salim Selamat, Zahari Md Rodzi

To Link this Article: http://dx.doi.org/10.6007/IJARPED/v10-i3/10417

DOI:10.6007/IJARPED/v10-i3/10417

Received: 04 June 2021, Revised: 07 July 2021, Accepted: 29 July 2021

Published Online: 06 August 2021

In-Text Citation: (Mohmad et al., 2021)

To Cite this Article: Mohmad, S., Ibrahim, M. S., Mohamad, W. N., Selamat, M. S., \& Rodzi, Z. M. (2021). An Efficiency Analysis of Lecturer Engagement Through Virtual Learning Using Microsoft Teams During Covid19 Pandemic. International Journal of Academic Research in Progressive Education and Development, 10(3), 140-149.

Copyright: (C) 2021 The Author(s)

Published by Human Resource Management Academic Research Society (www.hrmars.com)

This article is published under the Creative Commons Attribution (CC BY 4.0) license. Anyone may reproduce, distribute, translate and create derivative works of this article (for both commercial and non-commercial purposes), subject to full attribution to the original publication and authors. The full terms of this license may be seen at: http://creativecommons.org/licences/by/4.0/legalcode

Vol. 10(3) 2021, Pg. 140 - 149

http://hrmars.com/index.php/pages/detail/IJARPED JOURNAL HOMEPAGE

Full Terms \& Conditions of access and use can be found at http://hrmars.com/index.php/pages/detail/publication-ethics 


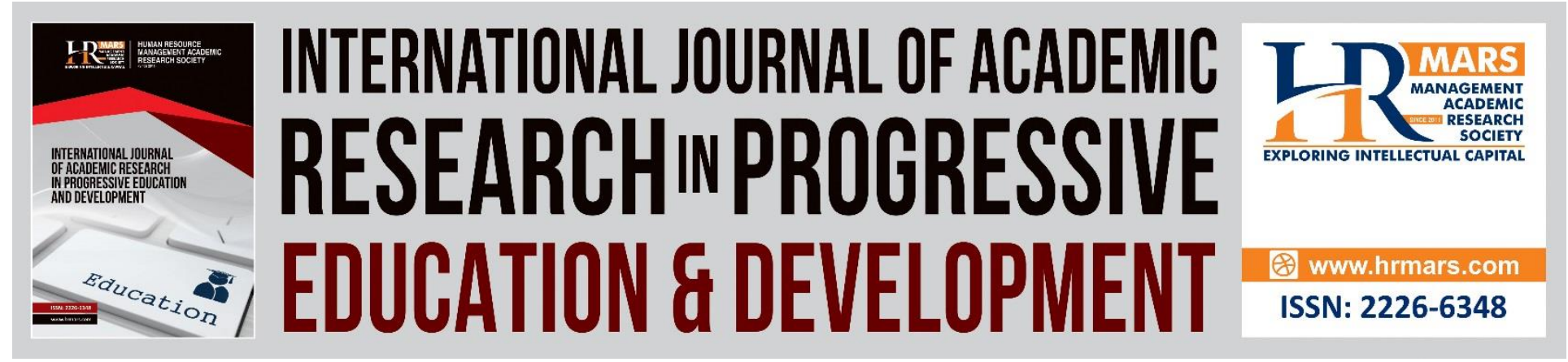

\title{
An Efficiency Analysis of Lecturer Engagement Through Virtual Learning Using Microsoft Teams During Covid-19 Pandemic
}

\author{
Sarahiza Mohmad ${ }^{1}$, Mohd Syahril Ibrahim², Wan Normila \\ Mohamad $^{3}$, Mat Salim Selamat ${ }^{4}$, Zahari Md Rodzi $^{5}$ \\ 1,4,5Fakulti Sains Komputer dan Matematik, Universiti Teknologi MARA Cawangan Negeri \\ Sembilan, Kampus Seremban, Malaysia, ${ }^{2}$ Fakulti Undang-undang, Universiti Teknologi MARA \\ Cawangan Negeri Sembilan, Kampus Seremban, Malaysia, ${ }^{3}$ Fakulti Pengurusan dan Perniagaan, \\ Universiti Teknologi MARA Cawangan Negeri Sembilan, Kampus Seremban, Malaysia \\ 5Email: zahari@uitm.edu.my
}

\begin{abstract}
COVID-19's spread has altered the learning process at all educational levels, resulting in the proliferation of virtual classrooms throughout the world. The purpose of this study is to determine lecturer satisfaction with Microsoft Teams' use in online learning during the COVID19 pandemic. This way, we can implement the necessary improvements to ensure that students and lecturers are satisfied with their use of Microsoft Teams. Thirty-four lecturers from UiTM Cawangan Negeri Sembilan (UiTMNCS) participated in the study. Five criteria were used consisting of: Basic Microsoft Teams Functions, Discussion, Assessments, Features, and Attendance Form. Data were collected via questionnaires and then distributed to respondents via Google forms. All calculations were performed using the SPSS Statistics 26 software. The findings indicated that Basic Microsoft Teams Functions is the most effective criterion, while Assessments and Attendance Form is the least effective. The sub-criteria rating with the highest score is Creating a TEAM is simple and straightforward, and the lowest score indicates that Microsoft Teams works well even with slow internet. Chi-square test for independent variable shows there is no relationship between gender, residential area, faculties and teaching experience of UiTMCNS lecturers with sub criteria functions in Basic Functions of Microsoft Teams, Discussion, Assessments, Features and Attendance Form. Further research will be proposed to improve the attendance system by integrating it with the Microsoft team's attendance sheet.
\end{abstract}

Keywords: Microsoft Team, Google Form, Discussion, Assessments, Features, Attendance Form, Chi-Square Test for Independent 


\section{Introduction}

While some other digital learning platforms offer good learning experiences that enable students to actively engage with educational content, one should not miss the opportunity to navigate the experience with the Microsoft Teams, especially when dealing with a pandemic. According to Wea and Kuki (2021) students have a positive attitude towards the Microsoft Teams application. They can engage in online learning in the same way they would with traditional classroom instruction. As a result, students are motivated to engage in self-study and develop additional disciplines. Practically, Microsoft Teams has evolved into an effective medium for conducting online education. Rojabi (2020) noted that online classes delivered via Microsoft Teams provide an optimal learning environment for students. Majority of respondents in this study expressed a favourable opinion of the students' learning environment in an online class. The respondents' favourable assessment was based on their experience with online learning via Microsoft Teams. Also, online learning facilitates student-student interaction as well as studentteacher interaction. The good features offer in Microsoft Teams enables students to share files and content and includes screen sharing options that give teachers the flexibility to display whatever they want during class and indicating that it fosters an interactive environment between students, teachers, and the community both inside and outside the classroom (Bsharat \& Behak, 2021). Hence, Microsoft Teams promoted student engagement in online classes and that it was widely preferred by students (Ravi, 2020).

The Online Distance Learning (ODL) contents using Microsoft Teams and Office 365 features are enhanced with an organised integrated platform, ensuring a smooth teaching and learning process (Azizan, 2020) The convenient technique, which utilises readily available tools, promotes innovative methods for improving teaching and learning. As a tool to facilitate an online learning process in its features, Microsoft Teams 365's capabilities can be put to good use, particularly in the process of online teaching and learning. Microsoft Teams' capabilities for displaying interactions in discussion forums, the assessment process, and even a sufficient amount of data storage have been demonstrated through research (Wijayanto et al., 2021). Furthermore, students' preparedness not only indirectly assessed using Microsoft Forms as a substitute for recording students' attendance but also for viewing their opinions and status regarding teaching and learning (Azizan, 2021). It was discovered that many students are fully prepared, having received all important information via Microsoft Teams announcements on teaching and learning. Several features, such as downloading attendance and uploading files as a source, need to be modified to facilitate effective teaching from the teacher's perspective, the performance of basic functions and conducting assessments were straightforward and simple (Gayathri, 2020).

Research has shown that with the support of Microsoft Teams in an online cooperative learning by using Group Investigation (GI) teaching strategies, there is an increase in students' conceptual understanding ability (Dewi et al., 2021). Furthermore, there is a difference in students' ability to comprehend the matrix concept of online cooperative learning assisted by Microsoft Teams, whether it be provided through GI (government education) or conventional means (commercial education). Thirdly, it was found that students who learned through online cooperative learning with Microsoft Teams had a better understanding of the concept of the 
INTERNATIONAL JOURNAL OF ACADEMIC RESEARCH IN PROGRESSIVE EDUCATION AND

DEVELOPMENT

Vol. 10, No. 3, 2021, E-ISSN: 2226-6348 @ 2021 HRMARS

matrix of students in classes who received Gl-type online cooperative learning than students who learned in conventional classrooms.

It is also worth mentioning that Microsoft Team is incredibly user-friendly and easily adaptable by its users. According to Saranya (2020), faculty who are elderly and would have been practising exclusively with traditional methods of teaching are warming to the online teaching system, particularly Microsoft teams. This educator-friendly application has been an important assistance in the recent pandemic situation by bridging the gap between the student community and academics. Microsoft Teams is an approachable, adaptable platform whose primary feature is the ability to communicate informally and formally. The platform has a noticeable learning curve when switching between desktop and mobile modes, which proved to be a challenge for some participants. Microsoft Teams is an ideal platform for developing a CoP to assist students in developing the necessary 21st century skills for employment (Mazzola, 2019). In fact, Microsoft Team was rated as a user-friendly and highly satisfactory online education platform by students, but still required blended learning for the practical paper (Ravi, 2020).

Despite the positive responds given in using Microsoft Team, there are some hassles associated with its usage, including the adding non-institutional members to a classroom/team and some has expressed discomfort with the process of conducting a lab paper. There were affirmative responses to discussions conducted via Microsoft Teams, but teachers expressed dissatisfaction with the way Microsoft Teams functioned when internet speed was compromised (Basu, 2020; Ravi, 2020). It is suggested that ease of adding non-institutional participants to a desired group can be enhanced; practical (lab) teaching features can be made more convenient; a version of the tool that works with limited internet access can be designed; and class-notebook features can be simplified. MS-Teams have been an effective vehicle for delivering a nextgeneration teaching-learning experience (Basu, 2020).

\section{The Efficiency Analysis of Lecturer Engagement Through Virtual Learning Using Microsoft Teams \\ Demographic Description}

Data collections yield a total of 34 responses from lecturers of different faculties in UiTM Cawangan Negeri Sembilan (UTMCNS). The questionnaire for this study was adapted from Ravi (2020) and then accompanied with questions regarding attendance form. This survey uses Likert scale from "strongly disagree", "disagree", "neutral", "agree" to "strongly agree" in explaining lecturers' level of agreements about all functions in Microsoft teams.

Figure 1 shows that approximately 76.5\% (26) of the respondents were female, while $23.5 \%$ (8) were male. Figure 2 shows the residential area of respondents with $73.4 \%$ (25) of the respondents are staying within city area. 


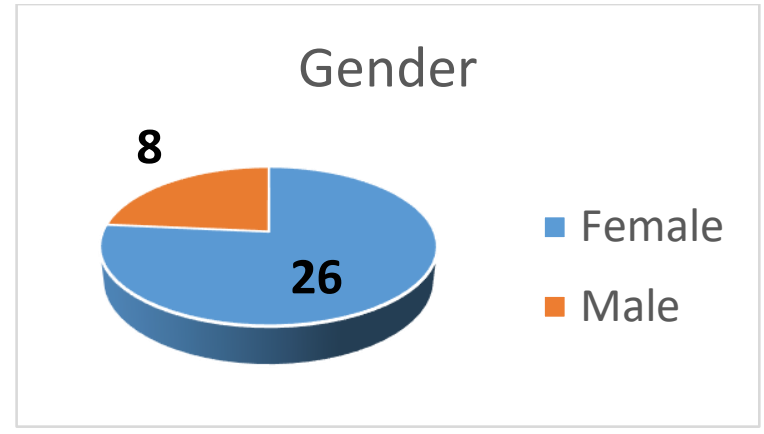

Figure 1. Gender

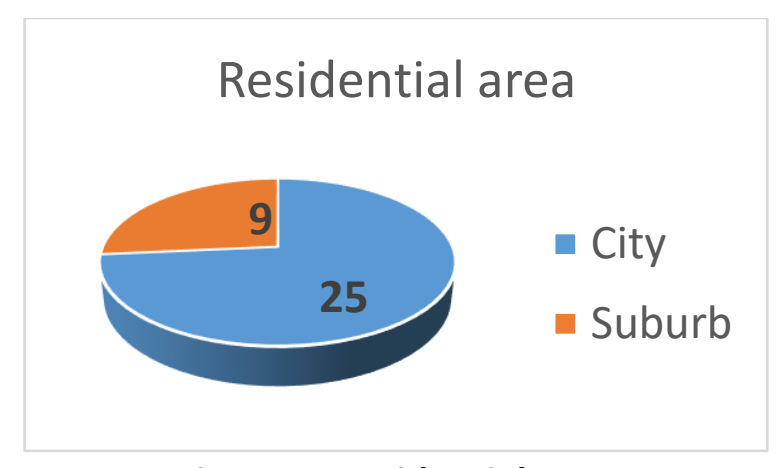

Figure 2. Residential Area

Respectively, Figure 3 and Figure 4 show the respondents' faculty affiliations and years of experience. Majority of the respondents are from the Faculty of Computer and Mathematics Sciences (FSKM) with teaching experience between ten to fourteen years.

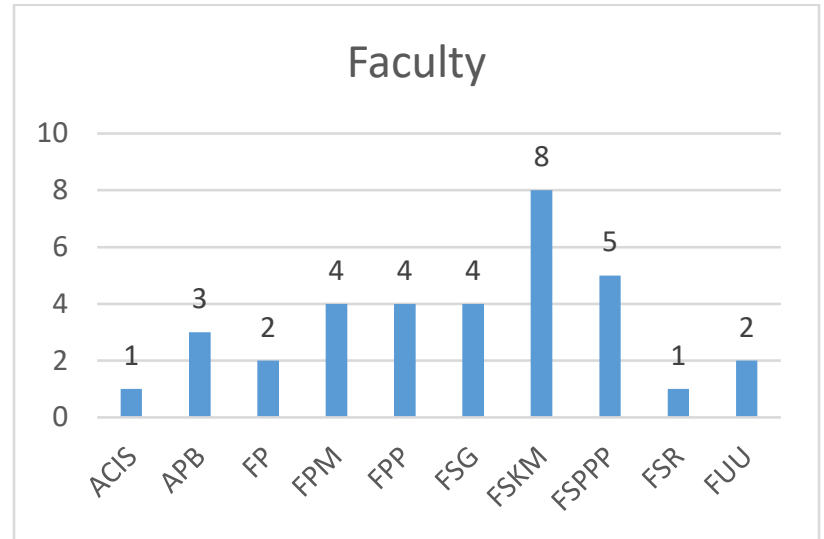

Figure 3. Faculties

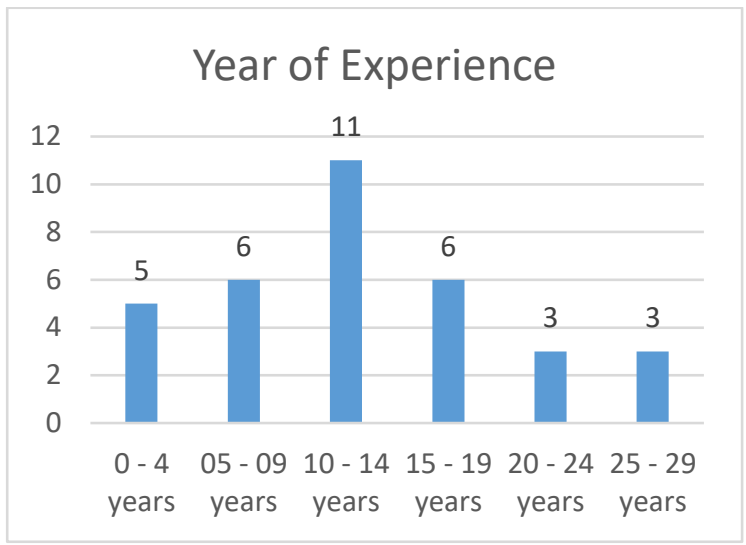

Figure 4. Years of Experience

\section{Efficiency Analysis of Lecturer Engagement Via Virtual Learning Using Microsoft Teams}

Table 1 shows that on average mean of 4.39, lecturers in UiTMCNS agreed that creating a TEAM is simple and easy task in basic functions in Microsoft Teams. However, questions on Microsoft Teams works well even if the internet speed is low resulted with the lowest result of mean 3.06. 
INTERNATIONAL JOURNAL OF ACADEMIC RESEARCH IN PROGRESSIVE EDUCATION AND DEVELOPMENT

Vol. 10, No. 3, 2021, E-ISSN: 2226-6348 @ 2021 HRMARS

Table 1: Basic Functions of Microsoft Teams

\begin{tabular}{|c|c|c|}
\hline & Mean & S. Deviation \\
\hline Joining an Existing TEAM is simple and easy. & 4.33 & 0.736 \\
\hline Creating a TEAM is simple and easy. & 4.39 & 0.747 \\
\hline $\begin{array}{l}\text { Adding members (who are in the institutional database) to the } \\
\text { created TEAM is easy. }\end{array}$ & 4.33 & 0.816 \\
\hline $\begin{array}{l}\text { Adding non-institutional member (guest) to the created TEAM } \\
\text { is easy. }\end{array}$ & 3.70 & 0.847 \\
\hline Begin a class using MEET NOW is simple and easy. & 4.33 & 0.890 \\
\hline $\begin{array}{l}\text { I am comfortable using Microsoft Teams to teach Theory } \\
\text { paper. }\end{array}$ & 4.18 & 0.635 \\
\hline I am comfortable using Microsoft Teams to teach Lab paper. & 3.55 & 0.869 \\
\hline I am comfortable using Microsoft Teams to host meetings. & 4.09 & 0.947 \\
\hline Microsoft Teams works well even if the internet speed is low. & 3.06 & 1.059 \\
\hline
\end{tabular}

In Table 2, most of the lecturers agreed that discussion in CHAT (conversation) with individual member option is an easy function to use showing the high mean of 4.12.

Table 2: Discussion

\begin{tabular}{|l|c|c|}
\hline & Mean & S. Deviation \\
\hline CHAT (conversation) with INDIVIDUAL member option is easy. & 4.12 & 0.696 \\
\hline $\begin{array}{l}\text { Voice Calling INDIVIDUAL registered member is simple and } \\
\text { easy. }\end{array}$ & 3.94 & 0.827 \\
\hline $\begin{array}{l}\text { Using CHAT (conversation) option for discussion during class is } \\
\text { easy. }\end{array}$ & 4.09 & 0.765 \\
\hline
\end{tabular}

On the other hand, Table 3 shows that all the lecturers agreed that assessments functions in Microsoft teams is simple and easy to use which showed a mean value between 3.55 to 3.94 .

Table 3: Assessments

\begin{tabular}{|l|c|c|}
\hline & Mean & S. Deviation \\
\hline Create QUIZ is simple and easy. & 3.61 & 0.899 \\
\hline Scheduling the QUIZ is simple and easy. & 3.67 & 0.924 \\
\hline Evaluating or grading the completed QUIZ is simple. & 3.55 & 0.905 \\
\hline Create ASSIGNMENT is simple and easy. & 3.94 & 0.788 \\
\hline Scheduling the ASSIGNMENT is simple and easy. & 3.94 & 0.827 \\
\hline Evaluating or grading the completed ASSIGNMENT is simple. & 3.67 & 0.890 \\
\hline
\end{tabular}

Table 4 covering the Features in Microsoft Team resulted with a 4.33 mean where respondents agreed that recording class features is a simple function. Whereas the functions of using FORMS for collecting a quick response during class is easy generated the lowest mean score of 3.73. 
INTERNATIONAL JOURNAL OF ACADEMIC RESEARCH IN PROGRESSIVE EDUCATION AND DEVELOPMENT

Vol. 10, No. 3, 2021, E-ISSN: 2226-6348 @ 2021 HRMARS

Table 4: Features

\begin{tabular}{|l|c|c|}
\hline & Mean & S. Deviation \\
\hline Recording class is simple. & 4.33 & 0.777 \\
\hline Scheduling a class is simple and easy. & 4.19 & 0859 \\
\hline Using CLASS NOTEBOOK is simple and easy. & 3.76 & 0.792 \\
\hline $\begin{array}{l}\text { Using FORMS for collecting a quick response during class is } \\
\text { easy. }\end{array}$ & 3.73 & 0.839 \\
\hline $\begin{array}{l}\text { Uploading resource for students as attachment or in the FILE } \\
\text { is easy. }\end{array}$ & 4.12 & 0.857 \\
\hline $\begin{array}{l}\text { Additional Apps which are embedded in Microsoft Teams will } \\
\text { be useful. }\end{array}$ & 3.85 & 0.712 \\
\hline
\end{tabular}

Table 5 shows the high mean of 4.00, indicating that downloading attendance form after the class is simple and easy to the lecturers. Whilst the lowest mean of 3.55 was on the functions of reminding student who fails to attend the class manually as simple and easy function.

Table 5: Attendance Form

\begin{tabular}{|l|c|c|}
\hline & Mean & S. Deviation \\
\hline $\begin{array}{l}\text { Downloading attendance form after the class is simple and } \\
\text { easy. }\end{array}$ & 4.00 & 0.935 \\
\hline $\begin{array}{l}\text { Identifying students' absence is simple and easy. } \\
\begin{array}{l}\text { Monitoring the duration of students' presence is simple and } \\
\text { easy. }\end{array}\end{array}$ & 3.58 & 1.001 \\
\hline $\begin{array}{l}\text { Reminding student who fails to attend the class manually is } \\
\text { simple and easy. }\end{array}$ & 3.55 & 1.034 \\
\hline Students take advantage of the current attendance system. & 3.73 & 0.911 \\
\hline
\end{tabular}

Figure 5 shows less than $50 \%$ respondents (44\%) being neutral on the functions of Microsoft Teams works well even during the internet speed is low with only $11.8 \%$ on strongly agreed. On the other hand, Figure 6 indicated the highest percentage of agreeable among lecturers on the option on the easy CHAT usage functions for discussion during class totalling to $82.3 \%$. Nonetheless, on the functions of simple and easy in creating assignment, Figure 7 shows that most respondents sided on the agree (50\%) and strongly agree $(23.5 \%)$ totalling to $73.5 \%$ indicating the satisfaction of Microsoft Teams platform. A total of $76.7 \%$ of respondents agreed on how simple and easy the function of scheduling a class in the online distance learning through Microsoft Teams (Figure 8). This high percentage further support the importance of Microsoft Teams in conducting online classes during this pandemic situation. Figure 9 further confirmed on the easy usage of Microsoft Teams attendance functions with $62 \%$ of the students taking advantage using the attendance system. 
INTERNATIONAL JOURNAL OF ACADEMIC RESEARCH IN PROGRESSIVE EDUCATION AND DEVELOPMENT

Vol. 10, No. 3, 2021, E-ISSN: 2226-6348 @ 2021 HRMARS

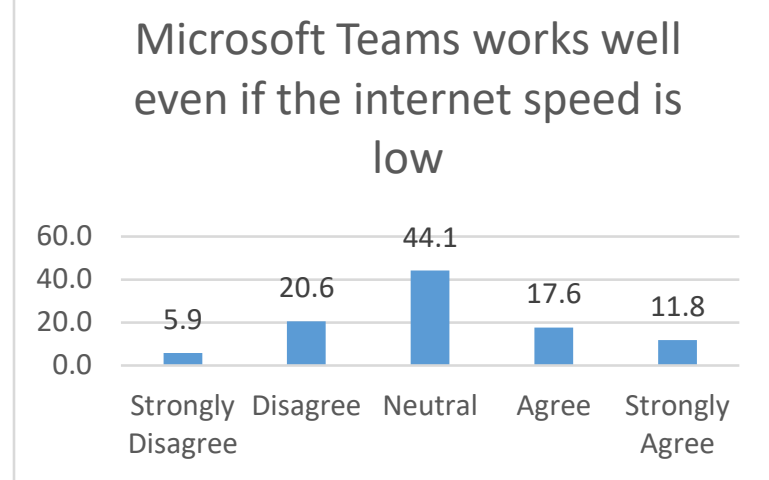

Figure 5. Microsoft Teams works well even if the internet speed is low

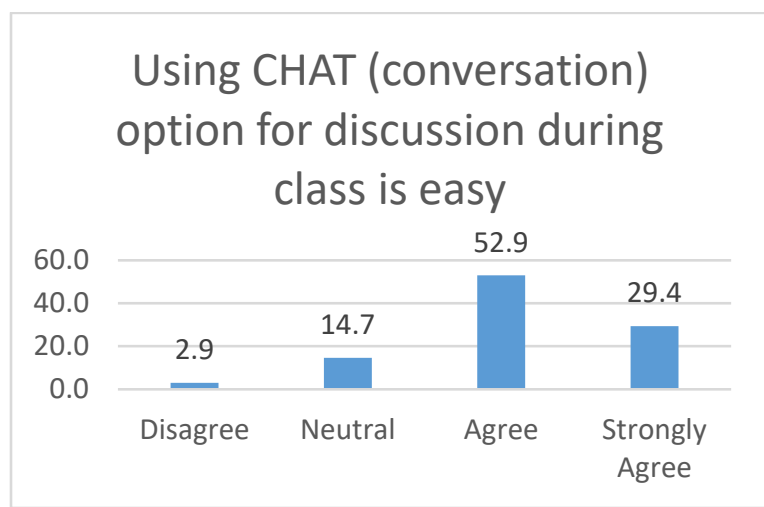

Figure 6. Using CHAT (conversation) option for discussion during class is easy

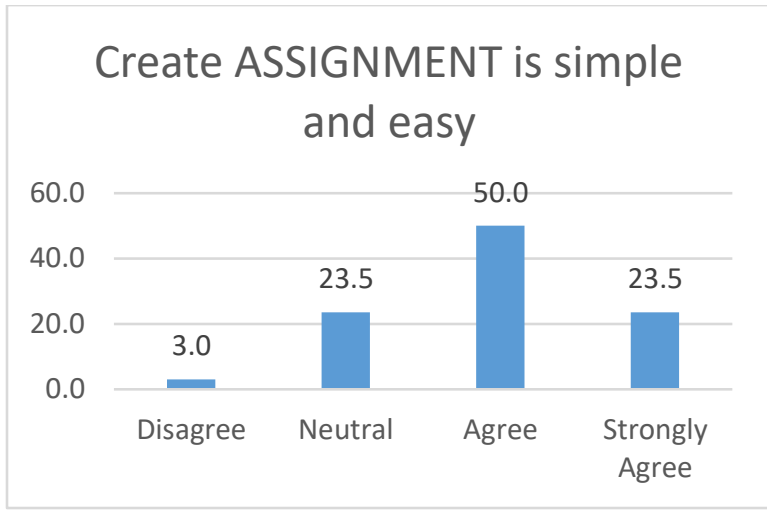

Figure 7. Create ASSIGNMENT is simple and easy

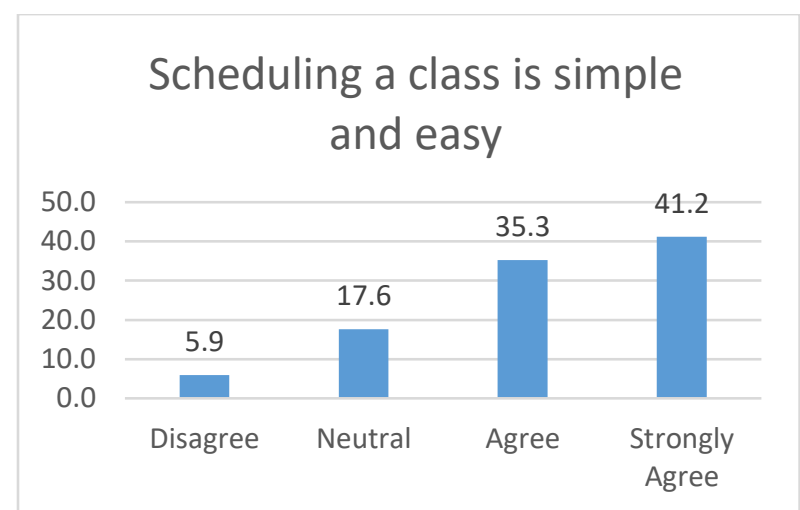

Figure 8. Scheduling a class is simple and easy

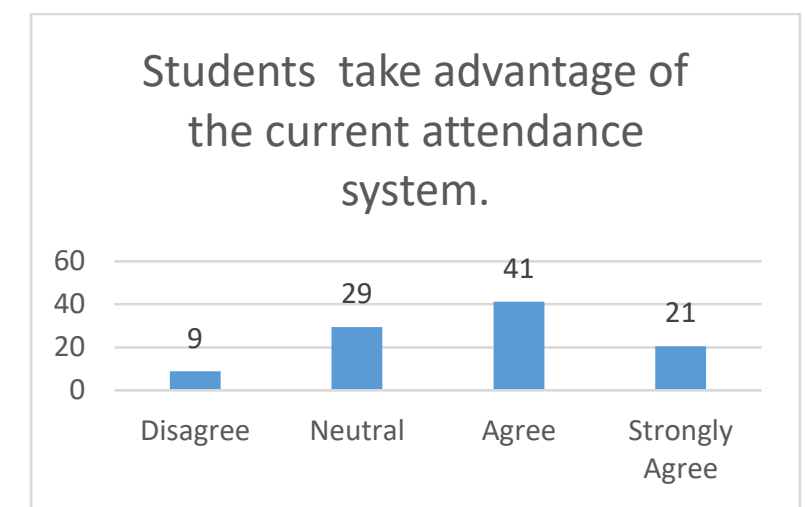

Figure 9. Students take advantage of the current attendance system 
DEVELOPMENT

Vol. 10, No. 3, 2021, E-ISSN: 2226-6348 @ 2021 HRMARS

\section{Chi - Square test for Independence}

In this study, Chi-square test is used to determine the independencies relationship of gender, residential area, faculties and teaching experience of UiTMCNS lecturers with questions related to functions in Microsoft Teams; Basic Functions of Microsoft Teams questions, Discussion, Assessments, Features and Attendance Form questions by comparing the $p$-values significance level. A significance level of 0.05 indicates that a $5 \%$ risk of concluding that an association between the variables exists when there is no actual association.

From Table 6, "Is there a significance relationship between Basic Functions of Microsoft Teams [Adding non-institutional member (guest) to the created TEAM is easy.] and Gender?". Table 6 resulted a Pearson Chi-Square of 1.377 with $p$-value of 0.711 which is more that $5 \%$ significance level, indicating that Basic Functions of Microsoft Teams [Adding non-institutional member (guest) to the created TEAM is easy] and Gender are statistically not significant. Hence, there is no relationship between gender and basic functions of Microsoft Teams (Failed to reject $H_{0}$ ).

Table 6: Chi-Square test of Basic Functions of Microsoft Teams [Adding non-institutional member (guest) to the created TEAM is easy] with Gender

\begin{tabular}{|l|c|c|c|}
\hline & Value & df & $\begin{array}{c}\text { Asymptotic } \\
\text { Significance (2-sided) }\end{array}$ \\
\hline Pearson Chi-Square & 1.377 & 3 & .711 \\
\hline Likelihood Ratio & 1.285 & 3 & .733 \\
\hline N of Valid Cases & 34 & & \\
\hline
\end{tabular}

$H_{0}$ : There is no relationship between Basic functions of Microsoft Teams [Adding noninstitutional member (guest) to the created TEAM is easy] and Gender.

$H_{1}$ : There is relationship $b$ between Basic functions of Microsoft Teams [Adding noninstitutional member (guest) to the created TEAM is easy] and Gender.

In Table 7, "Is there a significance relationship between Basic functions of Microsoft Teams [Microsoft Teams works well even if the internet speed is low] and Residential Area?". Results from Table 7, Pearson Chi-Square is 1.925 and the $p$-value is 0.750 with a Likelihood Ratio of 1.800 and $p$-value of 0.773 ( $p$-value more than $5 \%$ significance level). Therefore, it can be concluded that Basic functions of Microsoft Teams [Microsoft Teams works well even if the internet speed is low] and Residential Area are statistically not significantly associated (Failed to reject $\left.H_{0}\right)$.

Table 7: Chi-Square test of Basic Functions of Microsoft Teams [Microsoft Teams works well even if the internet speed is low] and Residential Area

\begin{tabular}{|l|c|c|c|}
\hline & Value & df & $\begin{array}{c}\text { Asymptotic } \\
\text { Significance (2-sided) }\end{array}$ \\
\hline Pearson Chi-Square & $1.925^{\mathrm{a}}$ & 4 & .750 \\
\hline Likelihood Ratio & 1.800 & 4 & .773 \\
\hline N of Valid Cases & 34 & & \\
\hline
\end{tabular}

$H_{0}$ : There is no relationship between Basic functions of Microsoft Teams [Microsoft Teams works well

even if the internet speed is low] and Residential Area. 
DEVELOPMENT

Vol. 10, No. 3, 2021, E-ISSN: 2226-6348 @ 2021 HRMARS

$\mathrm{H}_{1}$ : There is relationship between Basic functions of Microsoft Teams [Microsoft Teams works well even

if the internet speed is low] and Residential Area.

Table 8, "Is there a significance relationship between Assessments [Create QUIZ is simple and easy] and Experience?". Presentation of Pearson Chi-Square at 17.922 with the $p$-value of 0.267 with Ratio at 21.796 and $p$-value 0.113. This indicated that Assessments [Create QUIZ is simple and easy] and Experience are statistically not significantly associated (Failed to reject $\left.H_{0}\right)$.

Table 8: Chi-Square test of Assessments [Create QUIZ is simple and easy] and Experience

\begin{tabular}{|l|c|c|c|}
\hline & Value & df & $\begin{array}{c}\text { Asymptotic } \\
\text { Significance (2-sided) }\end{array}$ \\
\hline Pearson Chi-Square & $17.922^{\mathrm{a}}$ & 15 & .267 \\
\hline Likelihood Ratio & 21.796 & 15 & .113 \\
\hline N of Valid Cases & 34 & & \\
\hline
\end{tabular}

$H_{0}$ : There is no relationship between Assessments [Create QUIZ is simple and easy] and Experience

$H_{1}$ : There is relationship between Assessments [Create QUIZ is simple and easy] and Experience

Table 9, "Is there a significance relationship between Attendance Form [Downloading attendance form after the class is simple and easy] and Experience?". Statistically, Pearson Chi-Square result is 14.902 with p-value of 0.458 showing the Ratio of 16.822 and p-value 0.330 . Thus, this result shows that there is no relationship between Attendance Form [Downloading attendance form after the class is simple and easy] and Experience (Failed to reject $H_{0}$ ) as they are not significantly associated.

Table 9: Chi-Square test of Attendance Form [Downloading attendance form after the class is simple and easy] and Experience

\begin{tabular}{|l|c|c|c|}
\hline & Value & df & $\begin{array}{c}\text { Asymptotic } \\
\text { Significance (2-sided) }\end{array}$ \\
\hline Pearson Chi-Square & $14.902^{\mathrm{a}}$ & 15 & .458 \\
\hline Likelihood Ratio & 16.822 & 15 & .330 \\
\hline N of Valid Cases & 34 & & \\
\hline
\end{tabular}

$\mathrm{H}_{0}$ : There is no relationship between Attendance Form [Downloading attendance form after the class is simple and easy] and Experience

$\mathrm{H}_{1}$ : There is relationship between Attendance Form [Downloading attendance form after the class is simple and easy] and Experience

\section{Conclusion}

This study focuses on lecturer's engagement in virtual learning using Microsoft Teams as an effective tool on online teaching platform among lecturers during the pandemic situation. The study was conducted during the mid of semesters in Universiti Teknologi MARA (UiTM) Cawangan Negeri Sembilan when most of the lecturers are working from home, thus mechanism such as Microsoft Teams are very useful in the online distance learning. Majority 
of the respondents were comfortable with most of the basic functions of Microsoft Teams. The findings indicated that Basic Microsoft Teams Functions is the most effective criterion, with the least effective function of Assessments and Attendance Form. The highest score for the sub-criteria rating is the function of Creating a TEAM as simple and straightforward. The Chi-square test of the independent variable demonstrates that there is no correlation between gender, place of residence, university and faculty, and the years' lecturers have spent teaching with basic functions of Microsoft Teams, discussion, assessments, features, and attendance form. Microsoft Team platform was found to be incredibly user-friendly and easily adaptable by the lecturers. This platform is supportive and comfortable for fulfilling necessary aspects in teaching and learning thus helping researchers in understanding the digital learning platforms used in higher educations using Microsoft Teams as a teaching and learning tool. Future research could embark on an in-depth research of Microsoft Teams usage in other universities as well as making comparison with other digital platforms of teaching and learning.

\section{References}

Saranya, A. K. (2020). A Critical Study on the Efficiency of Microsoft Teams in Online Education. Efficacy of Microsoft Teams during COVID-19- A Survey, November, 310-323. https://www.researchgate.net/publication/345433571_A_Critical_Study_On_The_Effic iency_Of_Microsoft_Teams_In_Online_Education

Azizan, A. (2020). Engineering Academic Virtual Class with Microsoft Teams and Open-source Green Screen Superimpose Video Technique Teaching \& Learning Innovation. November.

Azizan, A. (2021). Engineering Students' Readiness And Preparedness On Teaching Engineering Students' Readiness And Preparedness On Teaching Materials With Microsoft Teams And. March.

Basu, S. (2020). A perspective on online-education: Survey on University Social Science faculties for a critical assessment of Microsoft Teams as a reference tool.

Astuti, D. A., Sa'dijah, C., \& Susiswo. (2021). Pembelajaran Kooperatif Daring Tipe Gi Berbantuan Microsoft Teams terhadap Pemahaman Konsep 1. Jurnal Riset Dan Konseptual, 6(2), 309-320.

Gayathri, R. (2020). Chapter - November 2020. In Efficacy of Microsoft Teams during COVID19- A Survey (Issue November, pp. 582-599). https://www.researchgate.net/publication/345904167

Mazzola, C. (2019). PhD in E-Research and Technology Enhanced Learning Microsoft Teams as Microsoft Teams as Digital Community of Practice in Higher Education? EDULEARN19 Proceedings.

Bsharat, R. K. T., \& Behak, F. (2021). The Impact of Microsoft Teams' App in Enhancing Teaching- Learning English during the Coronavirus (COVID-19) from the English teachers' perspectives' in Jenin city. Malaysian Journal of Science Health \& Technology, March. https://doi.org/10.33102/mjosht.v7i.116

Ravi, V. (2020). A Prognosticative Study on Faculty Satisfaction by Using Microsoft Teams in Online Teaching During the Covid-19 Pandemic Vignesh $R$, Research Scholar.

Wijayanto, Y. R., Andayani, A., \& Sumarwati, S. (2021). Utilization of Microsoft Teams 365 as an Alternative for Distance Learning Media Amid the Covid-19 Pandemic. International Journal of Multicultural and Multireligious Understanding, 8(2), 87. https://doi.org/10.18415/ijmmu.v8i2.2333 